RUTMech, t. XXXIII, z. 88 (4/16), październik-grudzień 2016, s. 335-346

Przemysław MOTYL ${ }^{1}$

Jan $\mathbf{L A C H}{ }^{2}$

\title{
CO-FIRING OF COAL WITH NATURAL GAS - COMPUTATIONAL SIMULATIONS
}

\begin{abstract}
The paper includes the results of computational tests conducted to compare coal combustion to the natural gas co-firing with coal in the combustion chamber of the conventional OP230 boiler with low-emission front burners and open-fire air (OFA) nozzles. It was shown that co-firing coal with the co-fuel with high content of methane can result in the reduction of NOx emissions about $40 \%$ compared with the coal combustion. The results obtained can be used as a benchmark for comparative computer tests of indirect co-firing of coal with syngas derived from wood- and agriculturally-based biomass and waste products.
\end{abstract}

Keywords: co-firing, boiler, low-emission combustion

\section{Introduction}

The energy sector is interested in energy-efficient and economically rational low-carbon technologies of electricity and heat production, including the use of biomass. One of these is the indirect co-firing wherein, the substitute of gaseous fuel in the form of a low calorific syngas produced from the highly efficient gasification of different fuel feedstocks is either co-fired with coal at the burners, separately burned at the special burners or used as reburning fuel [1-3]. The separation of gasification and co-firing processes is still relatively unpopular due to high unit investment $[4,5]$. However, this technology can be regarded as safer, more efficient and more environmentally friendly than direct co-firing. Delaying the commercial deployment of gasification in the power industry and utilities sector is the need to substantially increase the energy conversion efficiency of gasification process. This means that the syngas should contain a large share of combustible components, mainly of light hydrocarbons, and therefore primarily methane. In addition, it

\footnotetext{
${ }^{1}$ Autor do korespondencji/corresponding author: Przemysław Motyl, University of Technology and Humanities in Radom, ul. Malczewskiego 29, 26-600 Radom, +48 48361 71 23, e-mail: p.motyl@gmail.com

2 Jan Łach, University of Technology and Humanities in Radom, e-mail: lachjan@wp.pl
} 
needs to have the lowest possible content of tars, dioxins, furans and polyaromatic hydrocarbons (PAHs).

The indirect co-firing of the syngas with coal cannot lead to exceeding the legally permissible emission levels, including the $\mathrm{NO}_{\mathrm{x}}$ emissions the reduction of which from power boiler furnaces is one of the difficult problems associated with coal combustion. For this purpose, the so-called primary and secondary methods are used $[6,7]$. The first of them, based on the modifying the organization of the combustion processes, lead to reducing the $\mathrm{NO}_{\mathrm{x}}$ formation inside the combustion chamber while the latter consists in reducing the $\mathrm{NO}_{\mathrm{x}}$ emissions in the exhaust gas with the use of the efficient but expensive Selective Catalytic Reduction (SCR) technology. One of the important primary methods is the reburning or fueling in staging technology. In principle, one has to deal with the three-stage combustion of coal including: (i) primary combustion zone in which a main fuel is burnt; (ii) reburning zone with an injection of co-fuel establishing a fuel-rich zone; and (iii) burnout zone in which a secondary air is supplied. Reburning is still the subject of research in lab-scale, pilot and demo installations although its successive commercial environmentally friendly implementations in pulverized coal-fired boilers in the Japan known as MACT and A-MACT [8, 9] were fully successful and applied in new boiler installations. Similarly, effective reburning technologies were commercially implemented in the USA [10-12] while the full-scale tests have been conducted, e.g. in the UK [13]. Let us add that natural gas, very fine pulverized coal, coal emulsions and crude-oil were used as reburning hydrocarbon fuels. Each of these secondary fuels poses a number of technological and/or economic problems. To provide hydrocarbons for reburning in pulverized coal-fired boilers, the injection of syngas derived from gasification of different types of biomass and waste products (wood waste, agro biomass, bark, sawdust, peat, cardboard, railroad ties, plastics, municipal solid wastes, solid recovered fuels, etc.) was also investigated in lab-scale as well as pilot and demo installations. Such a technology is known as the indirect co-firing. Advantages and disadvantages of both direct and indirect biomass co-firing systems have been done e.g. in $[14,15]$. The commercial examples of the latter are as follows: (i) the Kymijärvi combined heat and power (CHP) plant near Lahti in Finland (167 MWe, 240 MWth) with the Foster Wheeler circulating fluidized bed (CFB) gasifier operating on woody biomass, peat, paper, cardboard, tires and plastics [16]; (ii) the Ruien coal-fired plant in Belgium (190 MWe) with the gasifier similar to that of the Kymijärvi CHP plant operating on wood chips, bark and board residues [17]; (iii) the coal-fired CHP unit (600 MWe, $350 \mathrm{MWt}$ ) of the Amercentrale power plant in Geertruidenberg in Netherlands with the CFB gasifier operating on wood fuels such as demolition wood [18]; and (iv) the Zeltweg power plant in Austria (344 MWt) (closed in 2001 for economic reasons) with the CFB gasifier operating on spruce bark, wood chips, sawdust, plastics railroad ties and old demolition 
wood $[19,20]$. Despite the lack of DeNOx installation, the reduction of $\mathrm{NO}_{\mathrm{x}}$ emissions from the above-listed installations was from 5 to $10 \%$ of that during coal combustion. Further installations are described e.g. in [21]. Difficulties related to the implementation of experiments caused that indirect co-firing processes are increasingly analysed via numerical simulations usually using ANSYS Fluent CFD program. Our numerical results, concerning woody biomass-based syngas co-firing with coal in the original combustion chamber of the conventional OP230 boiler manufactured by RAFAKO with eight lowemission burners located at three levels on the front wall, have been given in $[22,23]$. The input and some operating data were collected at the Białystok Thermal-Electric Power Station S.A. The woody biomass derived raw syngas containing $3 \%$ of methane was injected into combustion chamber via: (i) six nozzles added on the front wall at the level of the bottom row of burners [22]; and (ii) three nozzles located on the side wall below the OFA nozzles [23]. The heat replacement by the co-fuel was about $7 \%$. It was found that the reduction of $\mathrm{NO}_{\mathrm{x}}$ emission can reach about $10 \%$ [23] and about 20\% [22]. Below, we present the results of simulations of co-firing of coal with natural gas. Like this, we intend to identify the effect of co-fuel type with high content of methane for the formation of favourable conditions for the reduction of $\mathrm{NO}_{\mathrm{x}}$ in a fuel-riche zone of the OP230 boiler. It is assumed that the injection of natural gas was carried out as in [23]. The results obtained can be used as a benchmark for comparative computer tests of indirect co-firing of coal with syngas derived from wood- and agriculturally-based biomass and waste products in the combustion chamber of the OP230 steam pulverized coal-fired boiler. The natural gas is considered as the standard co-fuel since reburning works best with methane.

\section{Formulation of the problem}

The goal of our study is to compare the preliminary computational results with regard to the reduction in $\mathrm{NO}_{\mathrm{x}}$ emissions during co-firing of natural gas with coal relative to the baseline case when only coal is combusted under normal operation conditions of the OP230 boiler. Both simulations were carried out using ANSYS program. The input and some operating data, i.e.: coal properties and boiler's full-load rating data, were collected at the Białystok Thermal-Electric Power Station S.A. Boundary conditions were derived using data acquired from the boiler manual. The size of the boiler is $8 \times 26.7 \times 8.66 \mathrm{~m}$. The unit is originally equipped with eight low- $\mathrm{NO}_{\mathrm{x}}$ burners on the front wall manufactured by Ecoenergia, but it was assumed that only six of them are in operation. They are located equally at two heights: $y=7.4 \mathrm{~m}$ and $\mathrm{y}=9.5 \mathrm{~m}$, i.e. three at each height (Fig.1). The chemical composition of coal is given in Table 1 and its calorific value was assumed to be equal to $23.44 \mathrm{MJ} / \mathrm{kg}$. For simulation purposes, the dedicated nozzles supplying the combustion chamber 
with the natural gas were added on two walls at the height of the bottom row of burners y $=5.4 \mathrm{~m}$. Assuming 5\% (case 1) or $15 \%$ (case 2) of heat replacement by the supplemental fuel, we find the part of boiler power which should be obtained from combustion of natural gas. Knowing its lower heating value, we arrive to volume flow rate. The composition of natural gas is given in Table 2. As for OFA nozzles (after the boiler retrofit), four of them are installed on the front wall $(\mathrm{y}=13.7 \mathrm{~m})$ and two times more on the opposite wall $(\mathrm{y}=11.3 \mathrm{~m}$ and $\mathrm{y}=13.7 \mathrm{~m})$. The combustion and co-firing simulations were limited to a radiant furnace. This approach requires to keep the flue gas temperature distribution in the cross-section $\mathrm{y}=19 \mathrm{~m}$ corresponding to the inlet into the boiler convective section. It must be pointed out that a small correction of air distribution in the combustion chamber has been made. This was associated with the transferring a part of air mass flow rate from the burners zone to OFA nozzles to remain both the proportion of air to coal in coal burners and overall balance of air supplied to the boiler (Table 3). Such a treatment resulted in an air velocity increase in the nozzles and better mixing of the flue gas with secondary air. The methane introduced into the reburning zone produces the greatest possible number of hydrocarbon radicals $\mathrm{CH}_{\mathrm{i}}$ responsible for the NO reduction to primarily $\mathrm{HCN}\left(\Sigma \mathrm{CH}_{\mathrm{i}}+\mathrm{NO}=\mathrm{HCN}+\ldots\right)$. Next, in view of the oxygen deficiency, $\mathrm{HCN}$ is converted to amino radicals $\mathrm{NH}_{\mathrm{i}}$ which react with $\mathrm{NO}$ leading to the formation of molecular nitrogen $\left(\mathrm{N}_{2}\right)$. Finally: $\Sigma \mathrm{CH}_{\mathrm{i}}+\mathrm{NO} \rightarrow \mathrm{HCN} \rightarrow \mathrm{NH}_{\mathrm{i}} \rightarrow \mathrm{N}_{2}$. Intermediate reactions involve hydrogen $\mathrm{H}$ and hydroxyl $\mathrm{OH}$ radicals [24]. This mechanism of $\mathrm{NO}$ reduction justifies the need to maintain a low excess air coefficient $(\lambda=0.7$ to 0.9$)$ in the reburning zone. In many secondary reactions of $\mathrm{NH}_{2}, \mathrm{H}_{2} \mathrm{CN}$ and $\mathrm{HCNO}$ formation, highly reactive hydrocarbon free radicals, $\mathrm{CH}, \mathrm{CH}_{2}$ and $\mathrm{CH}_{3}$, are of essential meaning. These conditions are not conducive to the $\mathrm{NO}_{\mathrm{x}}$ formation in the boiler furnace; therefore, their reduction can reach up to $80 \%$ depending on the methane percentage of total fuel [25]. Results of laboratory tests with injection of methane into the reburning zone during coal combustion are demonstrated e.g. in [26]. The $\mathrm{NO}_{\mathrm{x}}$ content was as follows: $480 \mathrm{mg} / \mathrm{Nm}^{3}$ (at the inlet to the reburning zone), $120 \mathrm{mg} / \mathrm{Nm}^{3}$ (at the level of secondary combustion air), and $148 \mathrm{mg} / \mathrm{Nm}^{3}$ (at the outlet of the combustion chamber). Reduction in $\mathrm{NO}_{\mathrm{x}}$ emissions in real conditions (the Longannet plant - $600 \mathrm{MWe}$, the Denver plant $-172 \mathrm{MWe}$ ) have been described in [13] and [27]. It ranged from 40 to $70 \%$. In general, the efficiency of reburning depends also on excess air coefficient, stoichiometry and temperature of the reburning zone, flue gas and syngas compositions, residence time, etc. This means that many computational studies are needed to achieve the appropriate interrelationships. The OP230 boiler selected for our study is a unit in which the region of burners is the airdeficient combustion zone $(\lambda<1)$. To create conditions for the total carbon burnout, the secondary air is supplied into the combustion chamber through bottom and OFA nozzles. Such an oxygen distribution allows the examination 
of the placement of additional nozzles supplying the combustion chamber with syngas at the bottom burners level. In this way one can get an effect similar to the reburning. At the same time, the residence time of syngas particles in the combustion chamber is so long that promotes the destruction of harmful compounds that may arise in the process of gasification. Such an increase of fuel injection at the level of bottom burners should reduce the zone rich in oxygen derived from the additional air nozzles located on the side walls. This should translate into an increase of substoichiometric zone from bottom to upper burners. It was assumed in our computations that the first ones do not work. However, this procedure may give rise to an increased risk of sulfur corrosion. To avoid this, some additional shielding measures are needed.
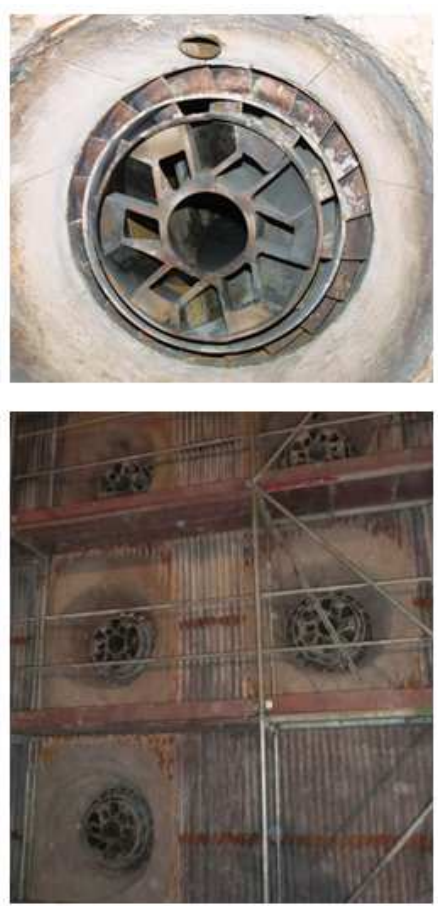

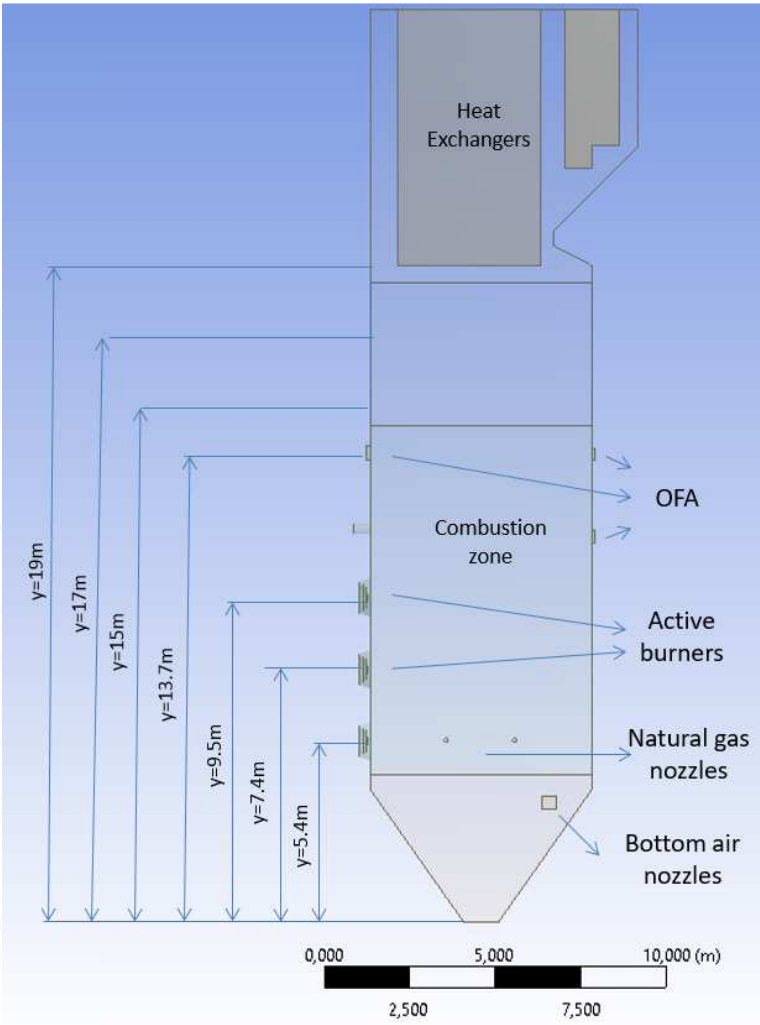

Fig. 1. Geometry of the OP 230 boiler at the Białystok Thermal-Electric Power Station S.A.

Table 1. Coal composition

\begin{tabular}{|c|c|c|c|c|c|c|c|c|}
\hline Component & Ash & Humidity & Carbon & Hydrogen & Oxygen & Nitrogen & Sulphur & Chlorine \\
\hline$\% \mathrm{wt}$ & 12.60 & 12.40 & 60.58 & 4.40 & 8.20 & 1.30 & 0.22 & 0.30 \\
\hline
\end{tabular}


Table 2. Natural gas composition

\begin{tabular}{|c|c|c|c|}
\hline Component & $\mathrm{CH}_{4}$ & $\mathrm{CO}_{2}$ & $\mathrm{~N}_{2}$ \\
\hline \% mol & 69.4 & 1.39 & 29.21 \\
\hline
\end{tabular}

Table 3. Operational conditions of co-firing

\begin{tabular}{|c|c|c|c|}
\hline Case description & Case 0 & Case 1 & Case 2 \\
\hline Coal consumption $[\mathrm{kg} / \mathrm{s}]$ & 8.24 & 7.82 & 7.00 \\
\hline Heat replacement $[\%]$ & 0 & 5 & 15 \\
\hline $\begin{array}{c}\text { Primary air volume flow rate }\left[\mathrm{Nm}^{3} / \mathrm{s}\right] \\
\text { and temperature }[\mathrm{K}]\end{array}$ & $\begin{array}{c}14.48 \\
378\end{array}$ & $\begin{array}{c}13.76 \\
378\end{array}$ & $\begin{array}{c}12.31 \\
378\end{array}$ \\
\hline $\begin{array}{c}\text { Secondary air volume flow to burners }\left[\mathrm{Nm}^{3} / \mathrm{s}\right] \\
\text { and temperature }[\mathrm{K}]\end{array}$ & $\begin{array}{c}25.96 \\
603\end{array}$ & $\begin{array}{c}24.66 \\
603\end{array}$ & $\begin{array}{c}22.07 \\
603\end{array}$ \\
\hline $\begin{array}{l}\text { Lower nozzles air volume flow rate }\left[\mathrm{Nm}^{3} / \mathrm{s}\right] \\
\text { and temperature }[\mathrm{K}]\end{array}$ & $\begin{array}{l}3.20 \\
603\end{array}$ & $\begin{array}{l}3.04 \\
603\end{array}$ & $\begin{array}{l}2.72 \\
603\end{array}$ \\
\hline $\begin{array}{l}\text { Air volume flow rate of OFA nozzles (front wall) }\left[\mathrm{Nm}^{3} / \mathrm{s}\right] \\
\text { and temperature }[\mathrm{K}]\end{array}$ & $\begin{array}{l}6.00 \\
603\end{array}$ & $\begin{array}{l}6.87 \\
603\end{array}$ & $\begin{array}{l}8.61 \\
603\end{array}$ \\
\hline $\begin{array}{l}\text { Air volume flow rate of OFA nozzles (rear wall) }\left[\mathrm{Nm}^{3} / \mathrm{s}\right] \\
\text { and temperature }[\mathrm{K}]\end{array}$ & $\begin{array}{l}9.00 \\
603\end{array}$ & $\begin{array}{c}10.30 \\
603\end{array}$ & $\begin{array}{c}12.92 \\
603\end{array}$ \\
\hline
\end{tabular}

\section{Results and discussion}

The selected results of computational fluid dynamics (CFD) successful simulations of the coal combustion (case 0) and its co-firing with methane (case 1 and case 2) are shown in Figs. 2-8. Temperature distribution in the boiler combustion chamber is illustrated in Fig. 2 while oxygen concentration is given in Fig. 3. There is considerable interest in the area-weighted values of temperature and concentrations of $\mathrm{O}_{2}$ and $\mathrm{NO}_{\mathrm{x}}$ corresponding to the characteristic heights in the boiler. They are shown in Figs. 4-8. It follows from Fig. 2 that in both cases considered, the co-firing leads to the diminution of zone with the temperature range $1600-1900 \mathrm{~K}$ at the OFA nozzles level. This results in reduced risk of high $\mathrm{NO}_{\mathrm{x}}$ emissions. It is also important that, the cofiring process does not lead to high increase in the average temperature in the top section of a combustion chamber compared with the coal combustion (Fig. 7). This does not result in an increase of flue gas loss and means that, we do not have to deal with the increase in $\mathrm{NO}_{\mathrm{x}}$ emissions due to additional formation of thermal $\mathrm{NO}_{\mathrm{x}}$. The co-firing process does not introduce significant changes in the operation of steam superheaters located above $y=19 \mathrm{~m}$.

The main burners region is characterized by a deficiency of oxygen $(\lambda<1)$. To establish complete burnout of coal, the secondary air is supplied via nozzles located on the side walls in the bottom level of main burners region and OFA nozzles. In addition, such a solution protects surfaces of combustion chamber against excessive sulphur corrosion and prolongs the combustion process by gradually supplying the air to fuel. Next, the dedicated nozzles delivering the natural gas and situated near bottom air nozzles (Fig. 1) limit the oxygen distribution in the bottom region of the combustion chamber. 
Thereby, an enlarged substoichiometric zone promotes the reduction of nitrogen oxides.

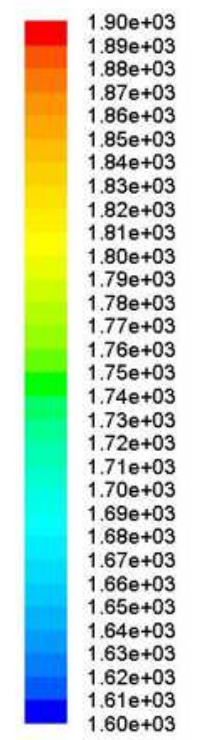

a)

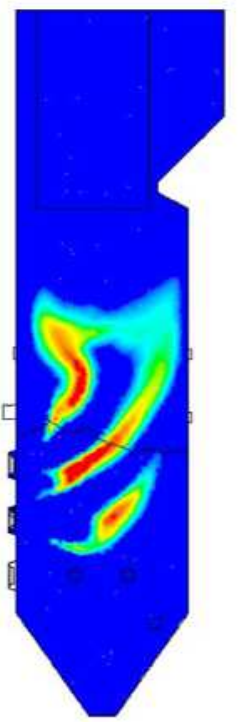

b)

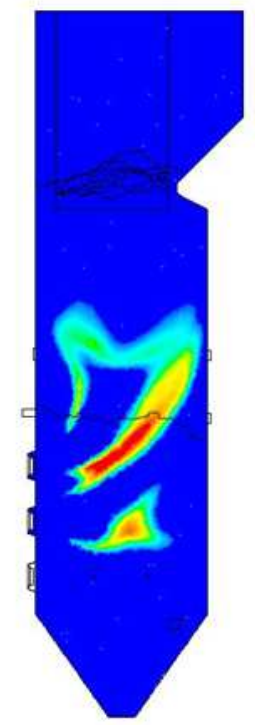

c)

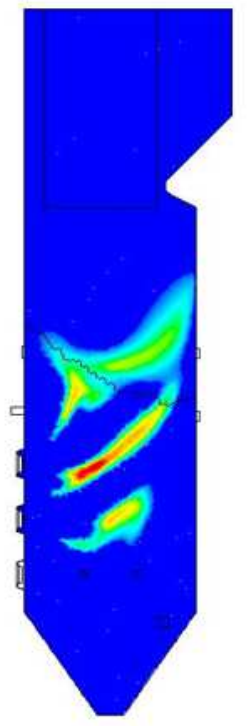

Fig. 2. Temperature $[\mathrm{K}]$ distribution in the boiler combustion chamber: a) coal combustion, case 0 ; b) co-firing, case 1 ; and c) co-firing, case 2

a)

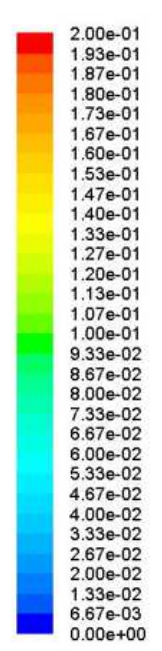

b)

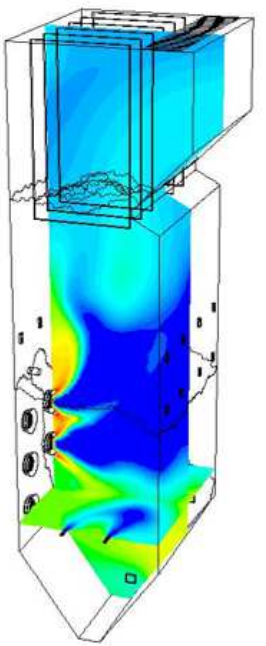

c)

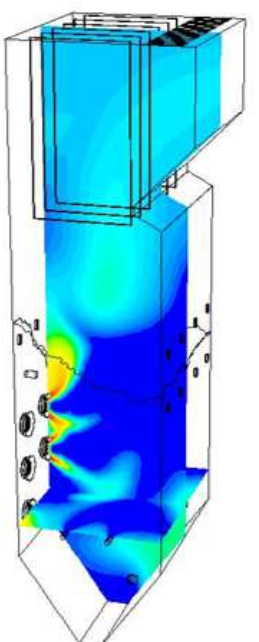

Fig. 3. $\mathrm{O}_{2}$ [mole fraction] concentration in the boiler combustion chamber: a) coal combustion, case 0 ; b) co-firing, case 1 ; and c) co-firing, case 2 


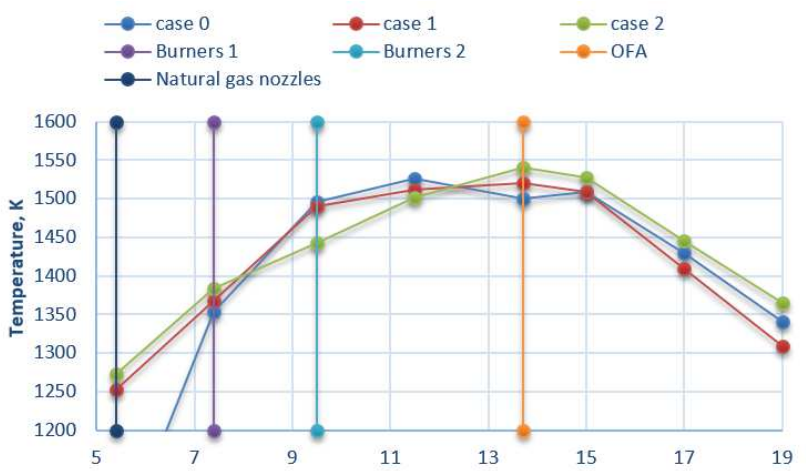

Fig. 4. Area-weighted average values of temperature as a function of furnace elevation y for coal combustion and its co-firing with $\mathrm{CH}_{4}$

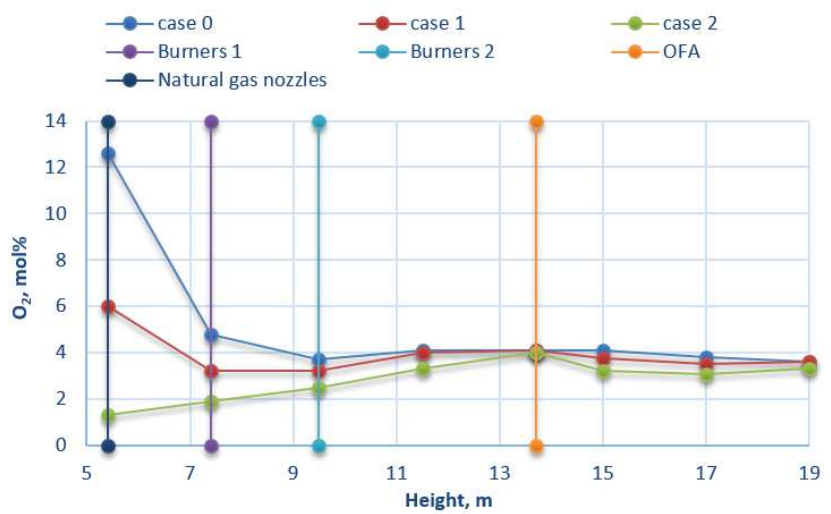

Fig. 5. Average concentration of $\mathrm{O}_{2}$ as a function of furnace elevation y for coal combustion and its co-firing with $\mathrm{CH}_{4}$

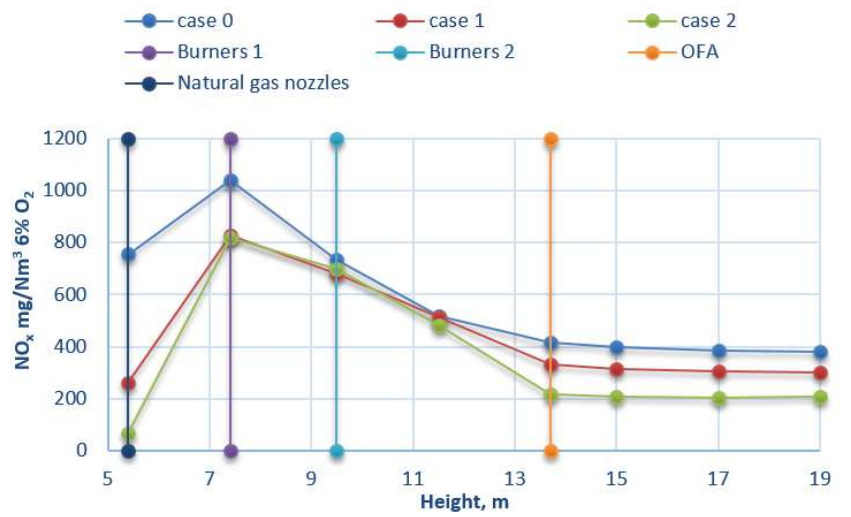

Fig. 6. Area-weighted average values of $\mathrm{NO}_{\mathrm{x}}$ concentration as a function of furnace elevation for coal combustion and its co-firing with $\mathrm{CH}_{4}$ (dry, $6 \% \mathrm{O}_{2}$ ) 
Let us observe that this effect is achieved at the expense of the increased risk of the protection of the combustion chamber screens against high temperature corrosion. It seems that for this reason, the proposed method of $\mathrm{NO}_{\mathrm{x}}$ reduction can be applied to a limited extent. The computational results (Fig. 8) showed that, the indirect co-firing coal with the co-fuel with high content of methane injected through additional nozzles added on two walls at the height of the bottom row of burners, can result in the reduction of $\mathrm{NO}_{\mathrm{x}}$ emissions about $40 \%$ compared with the coal combustion.

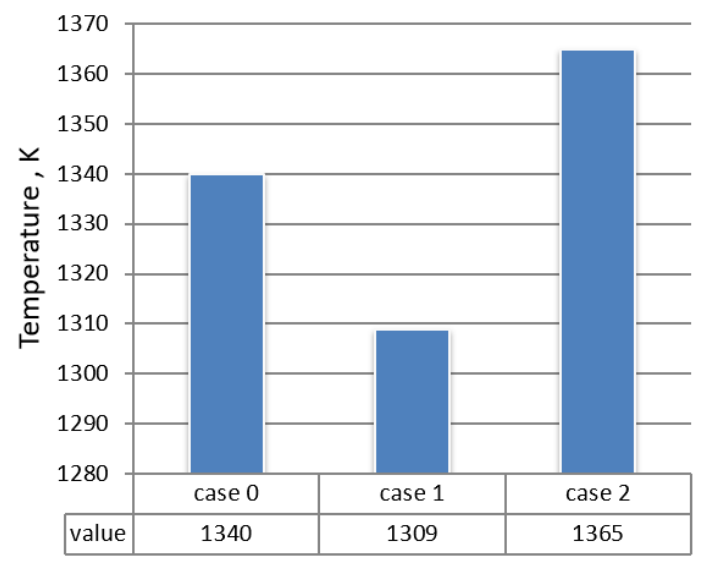

Fig. 7. Area-weighted average values of temperature on $\mathrm{y}=19 \mathrm{~m}$ cross sections in the boiler combustion chamber for: coal combustion, case 0 ; co-firing, case 1 ; and co-firing, case 2

a)

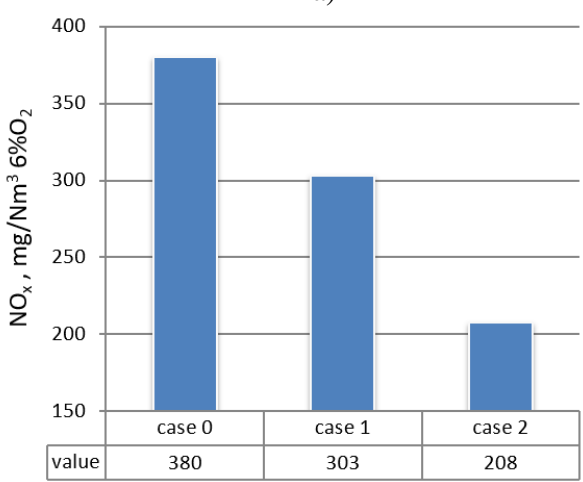

b)

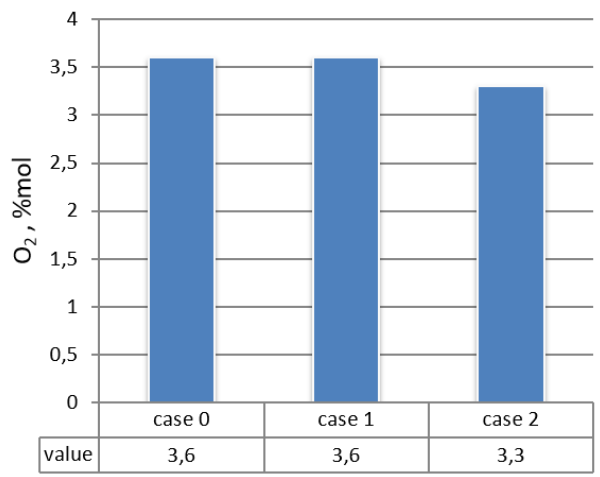

Fig. 8. Average concentration of $\mathrm{NO}_{\mathrm{x}}(\mathrm{a})$ and $\mathrm{O}_{2}$ (b) at cross-sections located at a height of $y=19 \mathrm{~m}$ in the boiler combustion chamber for: coal combustion, case 0 ; co-firing, case 1 ; and co-firing, case 2 


\section{Conclusions}

The computational tests of the co-firing coal with natural gas in the combustion chamber of the conventional OP230 boiler with low-emission front burners and OFA nozzles were designed to determine the benchmark for comparative computer tests of indirect co-firing of coal with syngas derived from wood- and agriculturally-based biomass and waste products. The preliminary computational results showed that high content of methane injected through additional dedicated nozzles can result in the considerable reduction of $\mathrm{NO}_{\mathrm{x}}$ emissions compared with the coal combustion. It would be interesting to determine the relationship between the scale of the reduction and the co-fuel type providing hydrocarbons to the combustion chamber. In addition, the indirect co-firing of the syngas with coal can be safer, more efficient and more environmentally friendly than direct co-firing. It cannot lead to the increased risk of the protection of the combustion chamber screens against high temperature corrosion. Since co-combustion of methane-rich gaseous fuel with coal translates into a high degree of $\mathrm{NO}_{\mathrm{x}}$ reduction, one should strive to conduct

a gasification process in gasifiers in such a way that the syngas obtained is characterized by the highest possible methane content. Such a co-fuel should be injected into the combustion chamber of the boiler through dedicated nozzles. It seems that, if the syngas has a low content of methane, just before its usage it should be mixed with natural gas. This way one can obtain the optimum degree of reduction in nitrogen oxides independently from the fuel utilized in a gasification process. This postulate seems to be reasonable, but requires further detailed research.

\section{References}

[1] Wu K.T., et al.: Study of syngas co-firing and reburning in a coal fired boiler, Fuel, 83 (2004) 1991-2000.

[2] Kalisz S., Pronobis M., Baxter D.: Co-firing of biomass waste-derived syngas in coal power boiler, Energy, 33 (2008) 1770-1778.

[3] Sami M., Annamalai K., Wooldridge M.: Co-firing of coal and biomass fuel blends, Progress Energy Combustion Sci., 27 (2001) 171-214.

[4] Quaak P., Knoef H., Stassen H.: Energy from biomass: a review of combustion and gasification technologies, World Bank technical paper 422, Energy series, 1999.

[5] McKenry P.: Energy production from biomass (part 3): Gasification technologies, Bioresource Technol., 83 (2002) 55-63.

[6] Kordylewski W. (red.): Niskoemisyjne techniki spalania w energetyce, Oficyna Wydawnicza Politechniki Wrocławskiej, Wrocław 2000.

[7] Wilk R.: Podstawy niskoemisyjnego spalania, Wydawnictwo Gnome, Katowice 2000 . 
[8] Fujima Y., Takahashi Y., Kunimoto T., Kaneko S.: Field application of MACT, Reburning Workshop, Örenäs Slott, Sweden, Nordie Gas Technology Centre 1991, pp. 7-27.

[9] Sato S., Kobayashi Y., Hashimoto T., Hokano M., Ichinose T.: Retrofitting of Mitsubishi low NOx system, Technical Review, 38 (2001) 111-115.

[10] U.S. Environmental Protection Agency, Center for Environmental Research Information, National Risk Management Research Laboratory, Office of Research and Development, Summary Report: Control of NOx emissions by reburning, EPA/625/R-96/001, Cincinnati 1996.

[11] Holland C.D.: A Summary of NOx reduction technologies, Texas Institute for Advancement of Chemical Technology, 2002.

[12] Watts J.U., Mann A.N., Russel, D.L. Sr.: An overview of NOx control technologies demonstrated under the Department of Energy's Clean Coal Technology Program, http://www.alrc.doe.gov.pdf.

[13] Golland E., Macphail J., Mainini F.G.: Longannet demonstrates gas reburn performance, VGB, 5 (1998) 79-83.

[14] Leckner B.: Co-combustion: A summary of technology, Thermal Sci., 11 (2007) $5-40$.

[15] Kalisz S., Pronobis M., Baxter D.: Co-firing of biomass waste-derived syngas in coal power boiler, Energy, 33 (2008), 1770-1778.

[16] Granatstein D.L.: Case study on Lahden Lampovoima gasification project Kymijärvi Power Station, IEA Bioenergy - Task 36 Report 2002.

[17] Jouret N., Helsen L., Van den Bulck E.: Study of the wood gasifier at the power plant of Electrabel-Ruien, Proc. European Combustion Meeting, Louvain-laNeuve 2005.

[18] Fernando R.: Cofiring high ratios of biomass with coal, IEA Clean Coal Centre 2012, CCC_194.pdf.

[19] Granatstein D.L.: Case study on BioCoComb biomass gasification project, Zeltweg Power Station, Austria, IEA Bioenergy - Task 36 Report 2002.

[20] Mory A., T. Zotter T.: EU-demonstration project BioCoComb for biomass gasification and co-combustion of the product-gas in a coal-fired power plant in Austria, Biomass \& Bioenergy, 15 (1998) 239-244.

[21] Fernando R.: Co-gasification and indirect cofiring of coal and biomass, IEA Clean Coal Centre 2009, CCC_158.pdf.

[22] Motyl P., Łach J.: Study of biomass syngas reburning in a pulverized coal fired boiler - numerical simulations, Heat Transfer and Renewable Sources of Energy 2014, A. A. Stachel and D. Mikielewicz (Editors), Szczecin 2014, pp. 39-46.

[23] Motyl P., Łach J.: Indirect co-firing coal with wood biomass syngas - numerical simulations, Logistyka, 6/2014.

[24] Patsias A.A., Nimmo W., Gibbs B.M., Williams P.T.: Calcium-based sorbents for simultaneous NOx/SOx reduction in a down-fired furnace, Fuel, 84 (2005) 1864-1873.

[25] Wang X.B., Zhao Q.X., Tan H.Z., Xu T.M., Hui S.E.: Kinetic analysis of nitric oxide reduction using biogas as reburning fuel, African J. Biotechnology, 8 (2009) 2251-2257. 
[26] Su S., Xiang J., Sun L., Zhang Z., Sun X., Zheng Ch.: Numerical simulation of nitric oxide destruction by gaseous fuel reburning in a single-burner furnace, Proc. Combustion Institute, 31 (2007) 2795-2803.

[27] Reburning technologies for the control of nitrogen oxides emissions from coalfired boilers, Clean Coal Technology Topical Report No.14, 1999.

\section{WSPÓŁSPALANIE WĘGLA I GAZU ZIEMNEGO - SYMULACJE OBLICZENIOWE}

\section{Streszczenie}

W pracy przedstawiono wyniki symulacji obliczeniowych przeprowadzonych w celu porównania spalania węgla ze współspalaniem gazu ziemnego i węgla w komorze paleniskowej konwencjonalnego kotła pyłowego OP230 wyposażonego w niskoemisyjne palniki. Wykazano, że współspalanie węgla z paliwem o wysokiej zawartości metanu może skutkować $40 \%$ redukcją związków NOx w porównaniu ze spalaniem tylko węgla. Prezentowane wyniki celu mogą być wykorzystane w celu określenia punktu odniesienia dla porównawczych wariantów badań komputerowych, w których dodatkowym współspalanym paliwem będzie gaz syntezowy pochodzenia rolniczego i pozyskany z biomasy drzewnej oraz odpadów.

Słowa kluczowe: współspalanie, kocioł, spalanie niskoemisyjne

DOI: $10.7862 / \mathrm{rm} .2016 .27$

Otrzymano/received: 15.09.2016 $r$.

Zaakceptowano/accepted: 14.11.2016 r. 